\title{
Safety and efficacy test to immersion vaccine against Streptococcus agalactiae and Aeromonas hydrophila for Tilapia (Oreochromis niloticus)
}

\author{
Desy Sugiani ${ }^{1}$, Nunak Nafiqoh ${ }^{1}$, Hessy Novita $^{1}$, Tuti Sumiati ${ }^{1}$, Septyan Andriyanto ${ }^{1}$, \\ Taukhid $^{1}$, Angela Mariana Lusiastuti ${ }^{1}$ \\ ${ }^{1}$ Research Station for Fish Disease Control, Research Institute for Freshwater Aquaculture and \\ Fisheries Extension (RIFAFE)
}

\begin{abstract}
Alternative prevention should be developed to control disease outbreaks in Tilapia culture caused by co-infections of Aeromonas hydrophila and Streptococcus agalactiae. Applications of vaccines with low cost and simple methods are highly recommended. This study was conducted to find out the safety and the efficacy of immersion vaccine in Tilapia used bivalent vaccines with formalin inactivated of $S$. agalactiae and $A$. hydrophila. Tilapia (Oreochromis niloticus) were divided into two groups, vaccinated and not vaccinated, with single and double doses immersion. The results showed that single and double doses of immersion vaccine were safe for fish (SR 100\%) and effectively increased the antibody titer values compared to non-vaccinated fish. The immersion vaccine method can be recommended as an alternative to controlled fish diseases, especially for both Motile Aeromonads Septicaemia and Streptococcosis caused by $A$. hydrophila and $S$. agalactiae infections, respectively.
\end{abstract}

\section{Introduction}

Good aquaculture practices made the production process and output are more predictable. Management of fish disease control with vaccination strategies that specifically protect both types of pathogens and fish species is recommended as a prevention method. Immersion vaccines for fish can be related to the easier practicality of all antigen preparations, reduced stress handling, minimal labor input, ideal for inducing the immune system, and can be used for all sizes of fish on a large scale [1].

Prevention of Streptococcosis and Motile Aeromonads Septicaemia (MAS) due to $S$. agalactiae and $A$. hydrophila infections with monovalent vaccines has been widely carried out in aquaculture. However, the bivalent vaccines for simultaneously protecting Tilapia from co-infection with these two types of diseases are not widely used in Indonesia. The fishes were injected with the bivalent vaccine of whole-cell S. agalactiae and A. hydrophila

\footnotetext{
${ }^{*}$ Corresponding author : desysugiani@gmail.com
} 
bacteria showed the Relative Percent of Survival (RPS) value up to 86.2 for challenged with single infection and 56.7 with co-infection [2]. Patent title for bivalent vaccine of $A$. hydrophila - S. agalactiae for Tilapia (Oreochromis niloticus) and manufacturing process with certificate number IDP000065965 has been possessed by Ministry of Marine Affairs and Fisheries in Indonesia patent law. The fish vaccine products require standardization from the authorized institution to issue the distribution permits. This study aimed to fulfill all license requirements for the fish vaccine products so that fish farmers can use them in aquaculture practices.

\section{Materials and Methods}

\subsection{Safety Test}

Analysis for the biologic product was done by the Station of Investigation for Fish Health and Environment, Directorate General of Aquaculture, Ministry of Marine Affairs and Fisheries. PCR method for bacterial species confirmation test on the bacteria content of the vaccine used $1 \mathrm{ml}$ of cell pellet sample from every 3 vials of vaccine whose randomized selected. The concentration and purity of the DNA were checked with nano drops, and a

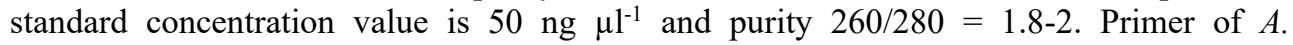
hydrophila Nuc-F CAGGATCTGAACCGCCTCTATCAGG; Nuc-R GTCCCAAGCTTCG AACAGTTTACGC; Aero-F GAGCGAGAagGTGACCACCAAGAAC; Aero-R TTCC AGTCCCACCACTTCACTTCAC; Ser-F ACGGAGTGCGTTCTTCCTACTCCAG; Ser-R CCGTTCATCACACCGTTGTAGTCG; Lip-F GACCCCCTACCTGAACCTGAGCTAC; and Lip-R AGTGACCCAGGAAGTGCACCTTGAG refers to [3] modified by [4]. Primer of $S$. agalactiae cps L-F CAATCCTAAGTATTTTCGGTTCATT; cps L-R TAGGAAC ATGTTCATTAACATAGC; cps J-F GCAATTCTTAACAGAATATTCAGTTG; cpsJ-R GCGTTTCTTTATCACATACTCTTG; cpsG-F ACATGAACAGCAGTTCAACCGT; cpsG-R ATGCTCTCCAAACTGTTCTTGT refers to modified method from [5]. And $10 \mu 1$ PCR amplicon was electrophoresed on $1.5 \%$ agarose gel with $1 \mathrm{x}$ TAE buffer and documentation of PCR results by gel doc.

Total protein measured by Bradford method [6]. The protein concentration of the sample was calculated based on a standard curve made from Bovine Serum Albumin (BSA). Especially in the purification stage, the protein is monitored by measuring its absorption at a wavelength of $280 \mathrm{~nm}$ (A280). The protein profile of the vaccines was tested using Sodium Dodecyl Sulphate-Polyacrylamide Gel Electrophoresis (SDS-PAGE) by the Laemmli method [6].

The safety test on fish was performed using two different doses (single doses $0.1 \mathrm{~mL} \mathrm{~L}^{-1}$ of water and double doses $0.2 \mathrm{~mL} \mathrm{~L}^{-1}$ of water) and immersed in the diluted vaccine for different immersion times ( 1 hour, 2 hours, and 3 hours) in separate containers. The water volume was reduced carefully, then readjusted after vaccination. Each container was filled with 30 fish (each $\pm 15 \mathrm{~g}$ ) with 3 replications. Observation of fish mortality and the clinical sign was carried out for 7 days. 


\subsection{Efficacy Test}

\subsubsection{Vaccine preparation}

The bivalent vaccine for Tilapia is made from whole-cell bacteria of $10^{11} \mathrm{CFU} \mathrm{mL}^{-1}$ of Aeromonas hydrophila AHL0905-2 - Streptoccocus agalactiae $\mathrm{N}_{14} \mathrm{G}$ inactivated to prevent Motile Aeromonas Septicemia (MAS), and Streptococcosis refers to [2].

\subsubsection{Antibody test}

Fish antibodies were measured from the vaccinated and unvaccinated fish serum using the direct agglutination method by dilution. Fish serum was taken every week from ten fishes in each treatment. Total agglutination was tested with the same bacteria as the vaccine content. Agglutination value was calculated based on the last microplate well that showed

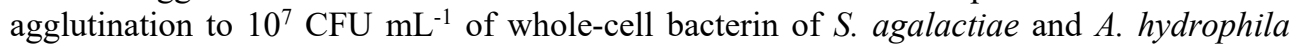
after a gradual dilution of $100 \mu \mathrm{L}$ serum with Phosphate-buffered saline (PBS), then the final value was converted in $\log -2$.

\subsubsection{Field trial}

Local farmers carried out field trials from Tasikmalaya - West Java Province in earthen ponds at the nursery stage. Fish with weight ranged from $1.5-2 \mathrm{~g}$ and stocking density of 50 fish.m ${ }^{-3}$ were cultured for 3 months with ad-libitum feeding. Fishes were acclimatized in quarantine ponds for three days before being vaccinated. Fish were immersed in vaccines $0.1 \mathrm{~mL} . \mathrm{L}^{-1}$ for three hours in plastic packaging bags for transportation. Field trials used three ponds, where the first and second ponds were filled with vaccinated fish, while the third pond was filled with the fish without vaccination.

\section{Result}

Several tests were carried out to check the quality and safety of vaccine products. The conclusion of the assay showed that bivalent vaccine of $S$. agalactiae and A. hydrophila conform to the quality requirements of fish vaccines in Indonesia (Table 1).

Table 1. The result of analysis for biologic product

\begin{tabular}{lll}
\hline \multicolumn{1}{c}{ Analyze } & \multicolumn{1}{c}{ Method spesificatian } & \multicolumn{1}{c}{ Result } \\
\hline Property & visual & Biege to white \\
Colour & visual & Liquid \\
Homogeneity & visual & Homogen \\
Acidity alkalinity & pH meter & 5 \\
$\begin{array}{l}\text { Contamination test : } \\
\quad \text { a. Salmonella } \text { sp }\end{array}$ & conventional & Negative (-) \\
$\quad$ b. Fungi & conventional & Negative (-) \\
$\begin{array}{l}\text { Purity test (bacterial species } \\
\text { which listed on the label): }\end{array}$ & & \\
$\begin{array}{l}\text { a. S. agalactiae } \\
\text { b. } \text { A. hydrophila }\end{array}$ & conventional & \\
& conventional & Pure / cocci \\
& & Pure / short-rod
\end{tabular}


Viability test

Sterility test conventional

FOHI (Indonesian

Pharmacopoeia of

Veterinary Medicine)
Not occur (bacterial growth)

Sterile

Three vials of vaccines were examined by PCR analysis for confirmation of vaccine content that indicated the vaccines were made from bacteria of $S$. agalactiae and $A$. hydrophila (Fig. 1, 2, and 3). Based on virulence genes (nuclease, aerolysin, serine protease, and lipase) of $A$ hidrophila and capsular polysaccharide CPS for serotype $S$. agalactiae.

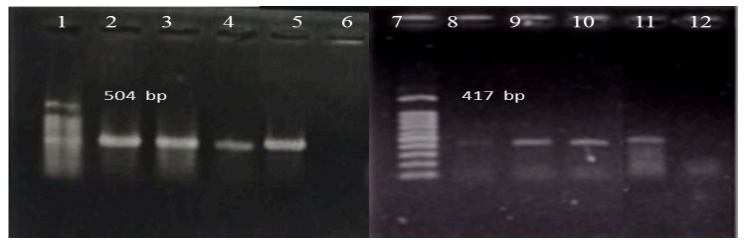

Fig. 1. PCR test interpretation of A. hydrophila from 3 different bottles. Nuclease (504 bp) and aerolysin $(417 \mathrm{bp})$. Nuclease and aerolysin are virulence genes for A. hydrophila; $(1,7)$ Marker 100bp; $(2,8)$ bottles $1 ;(3,9)$ bottle $2 ;(4,10)$ bottle $3 ;(5,11)$ positive control; $(6,12)$ negative control.

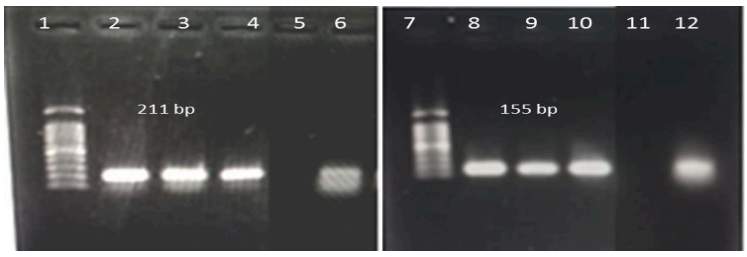

Fig. 2. PCR test interpretation of $A$. hydrophila from 3 different bottles. Serin protease (211 bp) lipase (155 bp). Serine protease and lipase are virulence genes for A. hydrophila; $(1,7)$ Marker 100bp; $(2,8)$ bottles $1 ;(3,9)$ bottle $2 ;(4,10)$ bottle $3 ;(5,11)$ negative control; $(6,12)$ positive control.

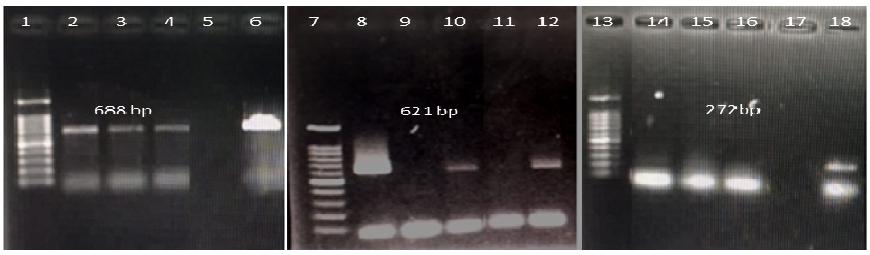

Fig. 3. PCR test interpretation of $S$. agalactiae from 3 different bottles. The capsular polysaccharide CPS L (688 bp) CPS J (621 bp) CPS G (272 bp). CPS L, J, and G is one of to determine the serotype of $S$. agalactiae; $(1,7,13)$ Marker $100 \mathrm{bp} ;(2,8,14$,$) bottles 1 ;(3,9,15)$ bottle $3 ;(4,10,16)$ bottle 3 ; $(5,11,17)$ negative control; $(6,12,18)$ positive control.

The total protein concentration of the vaccine was stable at 7 days storage at room temperature. The quality of protein vaccines from day $1-7$ at room temperature storage showed the same band with eight different molecular weights, and the most showed and the clear band was $52 \mathrm{kDa}$ (Table 2).

Table 2. Quantification of total protein and molecular weight of vaccines from day $1-7$ at room temperature storage 


\begin{tabular}{|c|c|c|}
\hline $\begin{array}{l}\text { Sample } \\
\text { (day) }\end{array}$ & $\begin{array}{c}\text { Total Protein } \\
\text { Concentration }\left(\mathrm{mg} \cdot \mathrm{ml}^{-1}\right)\end{array}$ & Protein size of vaccines (kDa) \\
\hline 0 & $3.485^{\mathrm{a}}$ & $\begin{array}{l}\text { 171.76; 150.40; } 126.00 ; 110.34 ; 52.00 ; \\
31.96 ; 25.62 ; 21.46\end{array}$ \\
\hline 1 & $3.312^{\mathrm{a}}$ & $\begin{array}{l}171.76 ; 150.40 ; 126.00 ; 110.34 ; 52.00 ; \\
31.96 ; 25.62 ; 21.46\end{array}$ \\
\hline 2 & $3.203^{\mathrm{a}}$ & $\begin{array}{l}171.76 ; 150.40 ; 126.00 ; 110.34 ; 52.00 ; \\
31.96 ; 25.62 ; 21.46\end{array}$ \\
\hline 3 & $2.972^{\mathrm{a}}$ & $\begin{array}{l}171.76 ; 150.40 ; 126.00 ; 110.34 ; 52.00 ; \\
31.96 ; 25.62 ; 21.46\end{array}$ \\
\hline 4 & $3.178^{\mathrm{a}}$ & $\begin{array}{l}171.76 ; 150.40 ; 126.00 ; 110.34 ; 52.00 ; \\
31.96 ; 25.62 ; 21.46\end{array}$ \\
\hline 5 & $3.102^{\mathrm{a}}$ & $\begin{array}{l}171.76 ; 150.40 ; 126.00 ; 110.34 ; 52.00 ; \\
31.96 ; 25.62 ; 21.46\end{array}$ \\
\hline 6 & $3.124^{\mathrm{a}}$ & $\begin{array}{l}171.76 ; 150.40 ; 126.00 ; 110.34 ; 52.00 ; \\
31.96 ; 25.62 ; 21.46\end{array}$ \\
\hline 7 & $3.034^{\mathrm{a}}$ & $\begin{array}{l}171.76 ; 150.40 ; 126.00 ; 110.34 ; 52.00 ; \\
31.96 ; 25.62 ; 21.46\end{array}$ \\
\hline
\end{tabular}

Remark: The same letter symbol indicates not significantly different $(\mathrm{p}>0.05)$

Group of fish with vaccine immersion treatment in the safety test found that the treatment without a vaccine, single and double doses of vaccine at 1,2 , and 3 hours immersion times showed 100 percent of survival rate. The results obtained that bivalent vaccines of $S$. agalactiae and A. hydrophila, which were inactivated, used formalin buffer, were safe to use.

The average value of the agglutination test of serum samples to $S$. agalactiae and $A$. hydrophila bacteria showed that the vaccinated fishes gave the best immune response than non vaccinated (Fig. 4-5). The antibody titer value proved that the specific immune response of vaccines reacted against homologous bacteria. The highest antibody titer was in the group of vaccinated fish against $S$. agalactiae at the third week, where up to $4 \log -2$ of titer. At the same time, the group of vaccinated fish against A. hydrophila showed the highest titer value in the second week up to $10 \log -2$ of titer.

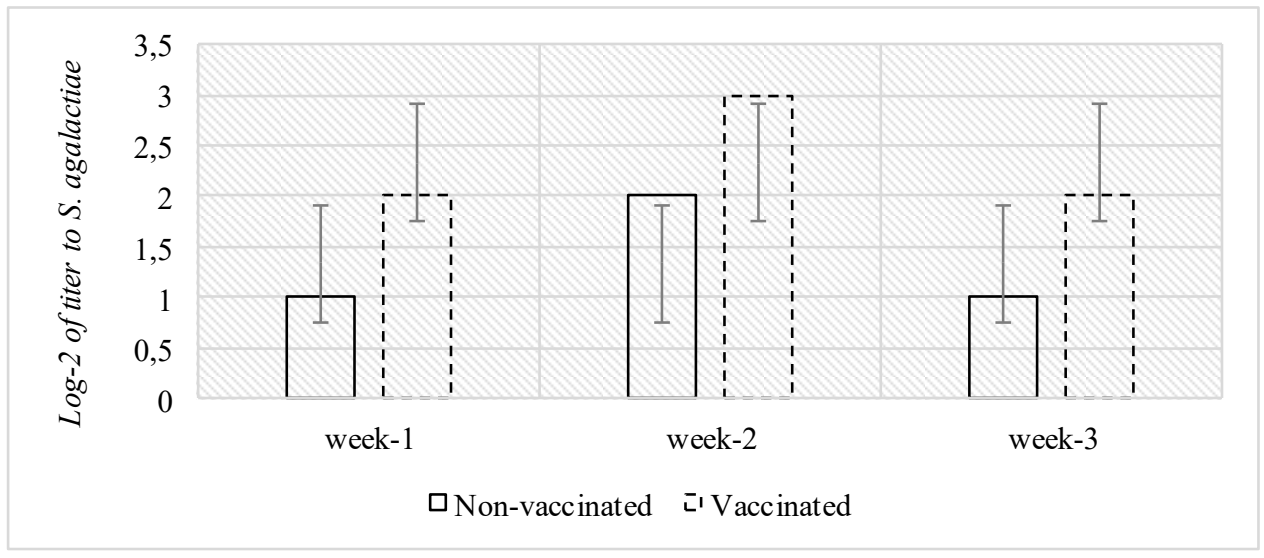

Fig. 4. Direct agglutinations result to $S$. agalactiae 


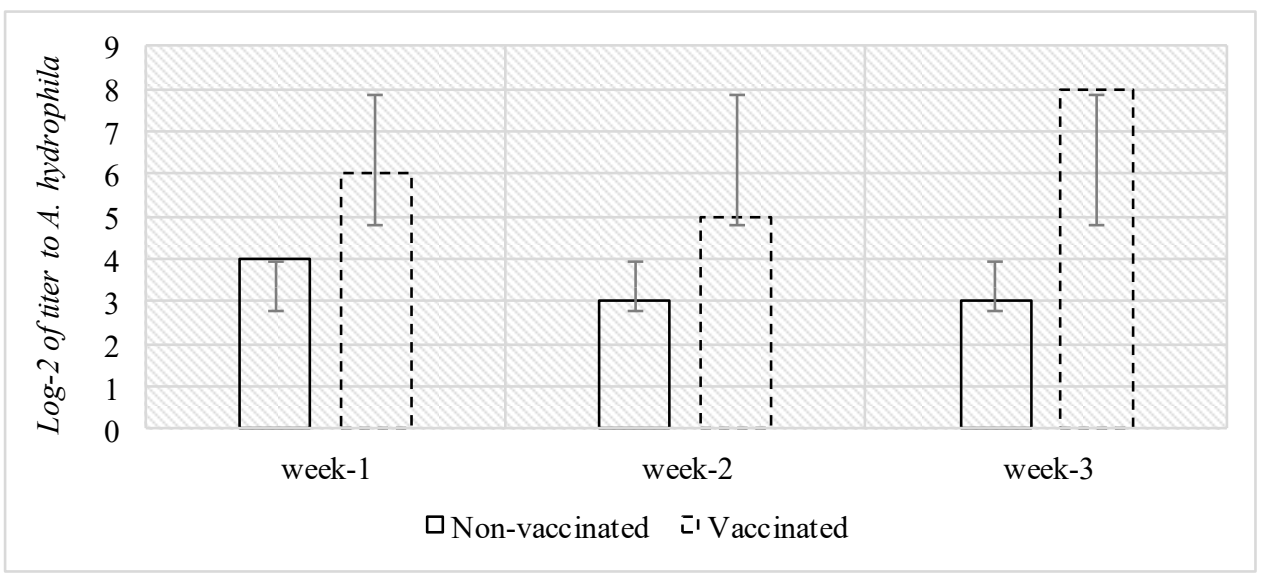

Fig. 5. Direct agglutinations result to in A. hydrophila

Field trial research showed that vaccinated fish had a higher survival rate compared to non-vaccinated fish, pond-1 differed in the survival of about $9.43 \%$. In comparison, pond-2 was different by $13.12 \%$, and the average body weight of fish are relatively similar in all ponds (Table 3 ).

Table 3. The field test result of a vaccinated and not vaccinated group of fishes

\begin{tabular}{ccc}
\hline Treatment of Fish & $\begin{array}{c}\text { Survival Rate } \\
(\%)\end{array}$ & $\begin{array}{c}\text { The average of fish weight } \\
(\mathbf{g})\end{array}$ \\
\hline Vaccinated from earthen pond - 1 & $60.86^{\mathrm{a}}$ & $41.5^{\mathrm{a}}$ \\
Vaccinated from earthen pond - 2 & $64.55^{\mathrm{b}}$ & $42.3^{\mathrm{a}}$ \\
Non-Vaccinated & $51.43^{\mathrm{c}}$ & $42.0^{\mathrm{a}}$ \\
\hline
\end{tabular}

Remark: Each column showed the same letter symbol indicates not significantly different and the different letter symbol indicates significantly different $(\mathrm{p}>0.05)$

\section{Discussion}

The results of SDS-PAGE in this research showed that the vaccines had the most cleared protein molecular weights at $52 \mathrm{kDa}$ that were in the protein range suggested by [7], the molecular weight of proteins for sub-units vaccines ranged from 47-75 kDa. Some protein weights from $S$. agalactiae and A. hydrophila bacteria have the potential to be developed as sub-unit vaccines. The storage process and shelf life can change the protein profile of the vaccine and reduce the level of protection. This vaccine product passed the quality test and was stable on storage for 7 days at room temperature and the level of protection. Most bacterial vaccines in fish cultured used formalin-inactivated strains [8]. The use of formalin not only for inactivated bacteria also as a preservative agent in vaccine products [9].

Stimulation of specific immune responses can increase the ability of fish against pathogens. The presence of specific antibodies will increase their protective abilities. This level of protection depends on the cross-reaction between the antigen components as a vaccine candidate, which aims to increase the immune response to homologous antigens. In this research, we used bacterin $S$. agalactiae and $A$. hydrophila virulent as bivalent vaccine compounds. This immersion vaccination study showed a significant increase in antibody titers. On day 21, after immersion from the post-vaccinated fish group, showed a higher serum agglutination titer than unvaccinated fish [10]. The antibody level peak values at the second week post-vaccination and the $S$. agalactiae immersion vaccine show that the whole 
cells vaccine were crushed into nanoparticles and gave positive signal uptake of antigen distributed in gills, oropharynx, kidney, liver, spleen, intestine, and fish skin $[1,11]$.

The effectiveness of vaccines for Tilapia is dependent on the specific strain of bacteria [12]. Immersion vaccination for Motile Aeromonads Septicaemia used inactivated A. hydrophila can increase RPS [13]. Fish vaccination used polyvalent vaccines to protect Tilapia against more than one type of disease through the immersion route is easier to administer and has a higher efficacy [14]. This study resulted in the best survival rate, only reached $13.12 \%$ lower than expected $(>15 \%)$. The level of protections value of vaccine application by immersion is not as high as RPS by injection. Most inactivated vaccines administered by immersion are weakly immunogenic and have low protection in fish [11]. Vaccination with hyperosmotic infiltration in optimum salinity $20 \mathrm{~g} \mathrm{~L}^{-1}$ gave a higher RPS of $88.24 \%$ against streptococcosis caused by Streptococcus agalactiae in Tilapia [15]. Coated antigen surface with nanoparticles mucoadhesive used chitosan biopolymer to provide "pathogen-like" properties can improved RPS level of Red Tilapia (Oreochromis sp.) due to administrations of immersion vaccination of Flavobacterium columnare [16].

\section{Acknowledgment}

This research was funded by the Indonesia Endowment Fund for Education (LPDP) Ministry of Finance The Government of The Republic of Indonesia, 2020 fiscal year period. Collaborated with PT. Caprifarmindo Laboratories as legitimate fish drugs plant in Indonesia.

\section{References}

1. X. Ke, Z. Liu, S. Chen, Z. Chen, D. Zhang, F. Gao, M. Lu, Aquaculture, 534 (2021)

2. D. Sugiani, Sukenda, E. Harris, A.M. Lusiastuti,JRA, 8, 2 (2013)

3. I.Y. Nam, K. Joh, J. Microbiol., 45, 4 (2007)

4. H. Novita, Muslikha, S. Pujiayanto, S. Nurjanah. Detection of virulent genes in Aeromonas hydrophila isolated from fish samples using PCR technique. Proceedings of Seminar Nasional Ikan $10^{\text {th }}$ and Kongres MII $5^{\text {th }} .577-590$ (2018)

5. M.M. Imperi, G. Pataracchia, L. Alfarone, G. Baldassarri, R. Orefici, A. Creti, J. Microbiol. Methods, 80 (2010)

6. D.M. Bollag, S.J. Edelstein. Protein methods (Department of Biochemistry University of Geneva - Switzerland: Wiley-Liss 1991)

7. D.J. Pasnik, J.J. Evans, V.S. Panangala, P.H. Klesius, R.A. Shelby, C.A. Shoemaker, J. Fish. Dis. 28 (2005)

8. A.E. Toranzo, J.L. Romalde, B. Magarinos, J.L. Barja, Opt. Med. 86 (2009)

9. D. Sugiani, A.M. Lusiastuti, Sukenda, E. Harris, JRA 9, 3 (2014)

10. B.C. Silva, M.L. Martins, A. Jatobá, C.C.B. Neto, F.N. Vieira, G.V. Pereira, G.T. Jerônimo, W.Q. Seiffert, J.L.P. Mouriño, Pesq. Vet. Bras. 29, 11 (2009)

11. J. Bøgwald, R.A. Dalmo. Review on Immersion Vaccines for Fish. Microorganisms. 7, 12 (2019)

12. M.S. Monir, S.M. Yusoff, A. Mohamad, M.Y. Ina-Salwan, J. Aqua. Anim. Health 32, $2(2020)$

13. C.A. Shoemaker, H.H. Mohammed, T.J. Bader, E. Peatman, B.H. Beck, Fish Shellfish Immun. 82, 239-242 (2018) 
14. K.M. Osman, L.A. Mohamed, H. Eman, A. Rahman, W.S. Soliman, WJFMS 1, 4 (2009)

15. D.P. Sari, Sukenda, M. Yuhana, S. Nuryati, Aqua. Int. 29, 1 (2021)

16. S. Kitiyodom, T. Yata, J. Yostawornkul, S. Kaewmalun, N. Nittayasut, K. Suktham, S. Surassmo, K. Namdee, C. Rodkhum, N. Pirarat, Fish Shellfish Immunol. 95 (2019) 